\title{
大阪医科大学病院における三歳児眼科検診精密検査受診児の予後
}

\author{
瀆村美恵子・平尾 真実・江富 朋彦・中村 桂子・澤 ふみ子 \\ 稲泉令巳子・清水みはる・筒井垔由美・菅澤＼cjkstart淳
}

大阪医科大学 眼科

\section{Prognosis of children underwent a detailed examination at Osaka Medical College Hospital after a vision-check program for three yeas old infant}

\author{
Mieko Hamamura, Mami Hirao, Tomohiko Etomi, Keiko Nakamura, \\ Fumiko Sawa, Remiko Inaizumi, Miharu Shimizu, Ayumi Tsutsui, Jun Sugasawa \\ Department of Ophthalmology, Osaka medical College
}

要 約

<目的 >三歳児眼科検診の目的である早期発見、早期治療の効果をみるために、就学時までに適切 な治療が行われたかどうかを検討した。

<対象と方法>対象は、平成 9 年 4 月から平成 15 年 3 月までの 6 年間に高槻市三歳児眼科検診の二次 検診で要精検となり、三次検診で大阪医科大学病院を受診した149名である。

＜結果と考案＞診断の結果は、要治療が114名 $(76.5 \%) 、$ 要経過観察が29名 $(19.5 \%) 、$ 異常なしが 6 名 (4\%) であった。その内訳は、屈折異常弱視 49 名、不同視弱視 17 名、斜視弱視6名、弱視のな い屈折異常26名、外斜視 49 名、内斜視13名などであった。眼鏡装用、遮閉法、Moore-Johnson変法 などにより治療を行った結果、屈折異常弱視、不同視弱視のほとんどが就学前に矯正視力（1.0）を 獲得していた。しかし、斜視弱視に関しては視力の向上がみられない例もあり、さらなる早期発 見・治療の必要も示唆された。斜視に関しては、外斜視の73\%は手術を念頭に経過観察したが、実 際の手術実施例は、経過観察可能者の $31 \%$ \%ちった。内斜視は、眼鏡装用にてその半数が眼位良好 になり、調節性内斜視に関して、時期を逃さず治療することができた。その他、下斜筋過動や上斜 筋麻痺は、全例就学前に手術を施行した。通院を中断した例が $21 \%$ $\%$ った。

＜結論＞三歳児眼科検診の成果は十分にあると考えられた。中断例をなくすためには、治療や経過 観察の必要性を理解してもらうことの大切さを再確認した。

別冊請求先（テ569-8686） 高梘市大学町 $2-7$

大阪医科大学 眼科

Tel. 072-683-1221 Fax. 072-681-8195

Key words : vision-check program for three years old infant, detailed examination, early disclosure, early treatment, drop-out

三歳児眼科検診、精密検查、早期発見、早期治療、通院中断 


\begin{abstract}
To examine whether the children were given an appropriate treatment by an entrance into an elementary school in consequence of early revealing and early treatment that was a purpose of a vision-check program for three years old infant.

Subjects and methods: Subjects were 149 children who underwent a third step detailed examination and treated at Osaka Medical College Hospital from April 1997 to March 2003 after a vision-check program for three years old infant in Takatsuki City.

Results and discussion: A third step detailed examination revealed 114 children (76.5\%) in need of treatments, 29 children (19.5\%) in need of follow-up and six (4\%) without any problem. They were ametropic amblyopia (49 children), anisometropic amblyopia (17children), strabismic amblyopia (6 children), refractive errors without amblyopia (26 children), exotropia (49 children), and esotropia (13 children) etc. In case of ametropic amblyopia or anisometropic amblyopia after treated by wearing glasses, occlusion method or Moore- Johnson method and, most cases with successfully obtained corrected visual acuity of 1.0 or better until school age. However, failed cases with strabismic amblyopia may indicate earlier disclosure and management is necessary. Although we planned surgical treatment for $73 \%$ cases of exotropia, only $31 \%$ of them actually underwent strabismus surgery. The results that a half of the cases with esotropia obtained a good eye position after wearing glasses implied the cases with accommodative esotropia had successful treatment timely. We performed a surgical treatment on all the cases with overacting inferior oblique muscle or with superior oblique palsy until school age. However, $21 \%$ of the cases dropped out of the treatments.
\end{abstract}

\section{I ．はじめに}

平成 3 年度より全国で開始された三歳児眼科 検診は、平成 9 年度の母子保健法の改正に伴い その業務が都道府県より市町村に移管された。 我々は、当初より高槻市の眼科検診に積極的に 参加し、実施母体が市町村へ移管される際にも 検診内容がより一層充実するよう取り組んでき た ${ }^{1)}$ 。高梘市では、3 歳 6 か月児を対象に一次 検診で家庭での視力検査と問診をアンケート方 式で行い、問題のあった幼児のみに受診を指示 し保健センターで二次検診を行っている。その 成果については、第60回弱視斜視学会において、 二次検診対象者中の要精検率は $2.5 \%$ でその中の 異常のない者は $5.1 \%$ と、精度の高い検診が行わ れていることを報告した ${ }^{2)}$ 。そこで次に検診の 目的である早期発見、早期治療の効果を検討す るために、今回、高柣市三歳児眼科検診の三次 検診として医療機関で精密健診を受けたものの うち、大阪医科大学病院眼科の受診者について 調査し、就学時までに適切な治療が行えたかど うか検討を行ったので報告する。

\section{II. 対象と方法}

対象は平成 9 年 4 月から平成 15 年 3 月までの 6 年間に高槻市三歳児眼科検診で要精検となり 医療機関を受診した371名のうち、当科を受診し 経過を追うことができた149名で、診断および治 療の内容、その後の経過について検討を行った。

\section{III. 結 果}

三次検診として医療機関を受診した371名のう ち当科を受診したのは、169名で、そのうち検討 を行えたのは、149名であった。

1 . 診断結果

診断の結果は、要治療が114名 $(76.5 \%) 、$ 要 経過観察が29名（19.5\%）、異常なしが 6 名 （4\%）であった（図 1)。初診時診断の内訳を 表 1 に示す。2つ以上の診断がついたものは重 複して数えたが、弱視群、屈折異常群、斜視群 の各群内での重複はない。主なものは、屈折異 常弱視 49 名、不同視弱視 17 名、斜視弱視 6 名、 


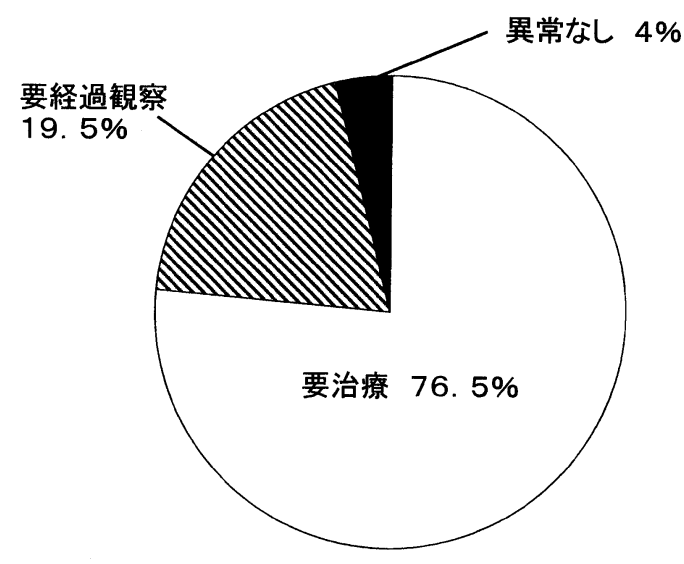

図 1 診断の結果

表 1 初診時診断の内訳

\begin{tabular}{|c|c|c|c|}
\hline 診 & 断 名 & 例数 & 合計 \\
\hline 弱 視 & $\begin{array}{l}\text { 届折異常弱視 } \\
\text { 不同視弱視 } \\
\text { 斜視弱視 }\end{array}$ & $\begin{array}{r}49 \\
17 \\
6\end{array}$ & 72 \\
\hline $\begin{array}{l}\text { 弱視のない } \\
\text { 屈折異常 }\end{array}$ & $\begin{array}{l}\text { 遠視-遠視性乱視 } \\
\text { 混合乱視 } \\
\text { 近視-近視性乱視 }\end{array}$ & $\begin{array}{r}11 \\
7 \\
8\end{array}$ & 26 \\
\hline 斜 視 & $\begin{array}{l}\text { 外斜視 } \\
\text { 内斜視 } \\
\text { その他の斜視 }\end{array}$ & $\begin{array}{r}49 \\
13 \\
4\end{array}$ & 66 \\
\hline その他 & $\begin{array}{l}\text { 眼瞼下垂 } \\
\text { 朝顔症侯群 } \\
\text { Duane症侯群 } \\
\text { 霞粒腫 } \\
\text { 角膜混濁 }\end{array}$ & $\begin{array}{l}2 \\
1 \\
1 \\
1 \\
1\end{array}$ & 6 \\
\hline
\end{tabular}

弱視のない屈折異常 26 名、外斜視 49 名、内斜視 13名などであった。

2. 治療内容および経過

\section{1 ) 屈折異常弱視}

屈折異常弱視は 49 例で、その調節麻盘下の 屈折值の分布を図 2 に示す。 $59 \%$ が遠視性乱 視で33\%が混合乱視であった。混合乱視は乱 視の度数が強いものが多かった。治療として は眼鏡を処方し常用を指示した。このうち 2 例は、治療途中に視力の左右差が出てきたた め、健眼遮閉やMoore-Johnson変法（以下 $\mathrm{M}-\mathrm{J}$ 変法) などの弱視治療も行った。途中 で転居3例、通院を中断してしまったもの 6 例、障害があり視力が十分確認できないもの 3 例を除く37例中35例（95\%）が、治療によ り（1.0）以上の字ひとつ矯正視力を獲得し

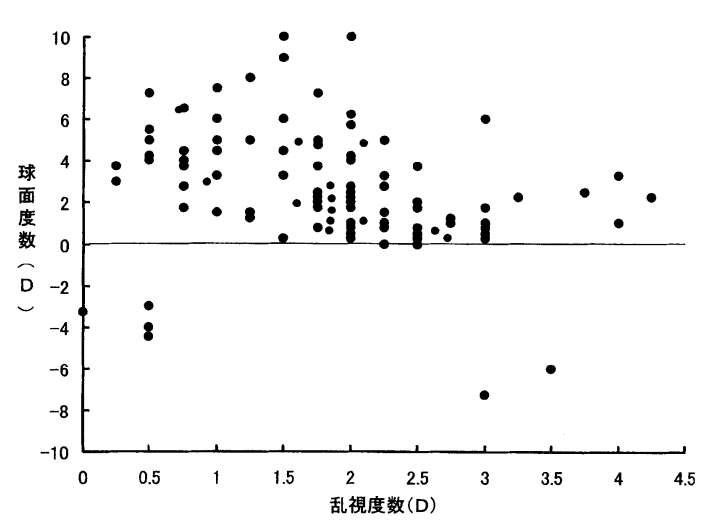

図 2 屈折異常弱視の調節麻痺下の屈折值

た。残りの2例は、潜伏眼振があり矯正視力が （0.8）までしか確認できていないもの 1 例、 矯正視力（0.7）で治療中のもの 1 例（現在 5 歳）である。（1.0）以上の視力が得られるま での期間は、最も長いもので 33 カ月であり、 就学までには治癒していた（図 3 )。

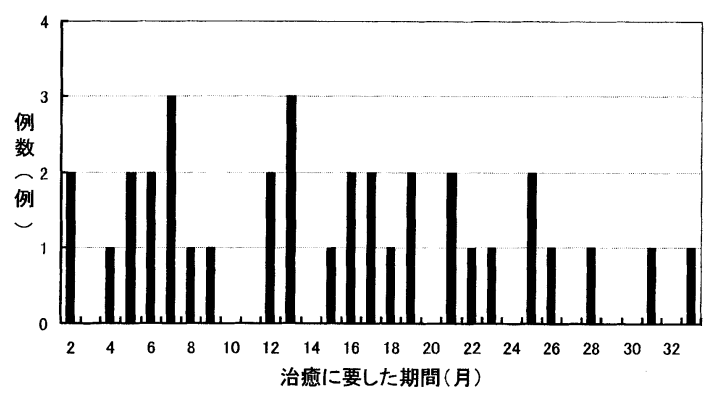

図 3 屈折異常性弱視の治療期間

2 ) 不同視弱視

不同視弱視は17例で、その弱視眼の屈折値 の分布を図 4 に示す。遠視および遠視性乱視 が多く、88\%であった。不同視差は、図 5 の ように $2.0 \mathrm{D}$ から $5.5 \mathrm{D}$ まであったが、不同視差 の程度は軽いものが多かった。治療法として は、多動症のため眼鏡装用が難しいと思われ た 1 例と処方前に通院を中断してしまった 1 例を除く15例に眼鏡を処方し、その内の 12 例 には健眼遮閉および $\mathrm{M}$ - J 変法などの弱視治 療を行った。治療の経過を図 6 に示す。治療 を行った全例が字ひとつ矯正視力（1.0）以上 


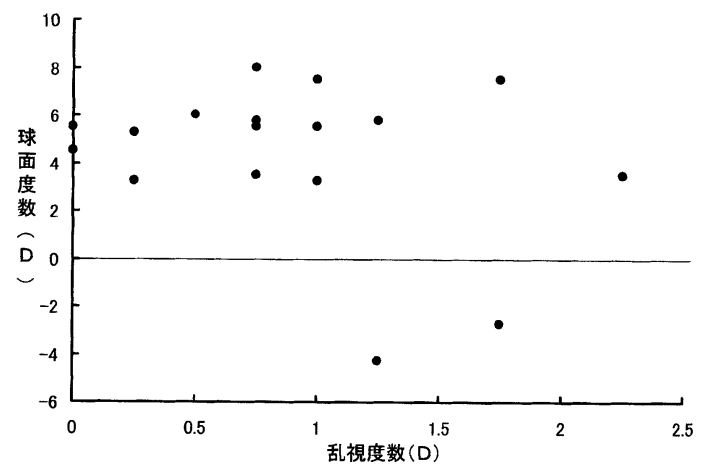

図 4 不同視弱視の弱視眼の調節麻痺下の屈折値

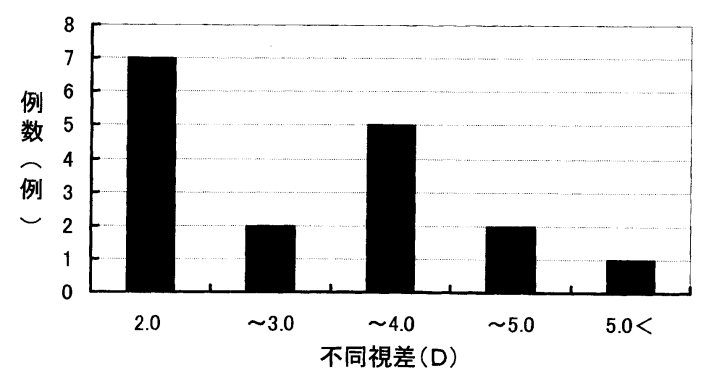

図 5 不同視弱視の不同視差

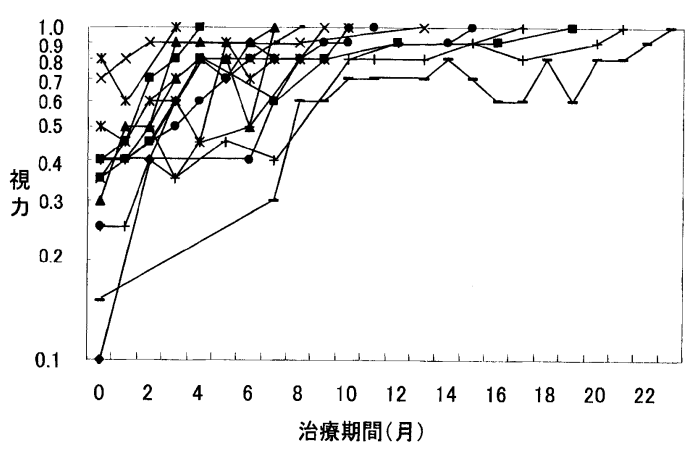

図 6 不同視弱視の治療経過

を獲得した。矯正視力が（1.0）以上得られる までの期間は 3 力月から 23 月で、就学前に は治癒していた。

3 ) 斜視弱視

斜視弱視は、 6 例中 4 例が内斜視、 2 例が 外斜視であった。治療法として、全例に眼鏡 装用と健眼遮閉および $\mathrm{M}-\mathrm{J}$ 変法などの弱視 治療を行った。治療の経過を図 7 に示す。治 療により字ひとつ矯正視力（1.0）を獲得した

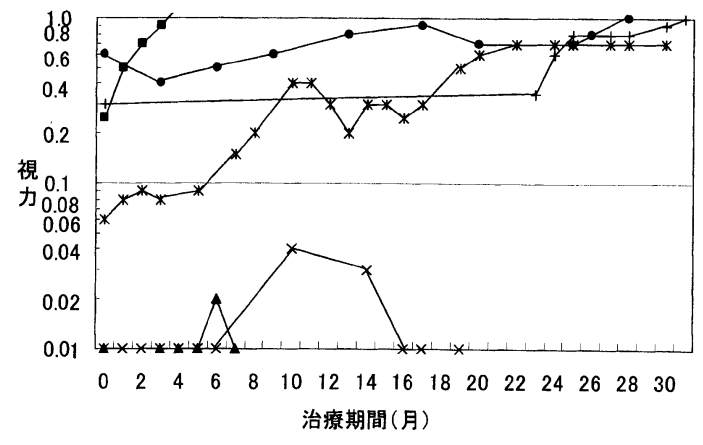

図 7 斜視弱視の治療経過

のは 3 例、矯正視力 $(0.7)$ で現在も治療中の もの 1 例（現在 6 歳）、視力がほとんど向上 しなかったものが 2 例であった。 2 例とも恒 常性の斜視で固視異常があり、不同視も合併 していた。

4 ）弱視のない屈折異常

弱視がないと思われる屈折異常は26例で、 その調節麻痺下の屈折值の分布を図 8 に示す。

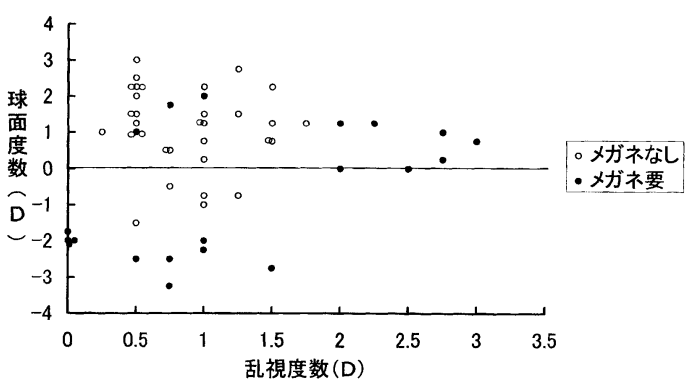

図 8 弱視がない屈折異常の調節麻痺下の屈折值 closed circleは眼鏡を処方したもの、open circleは眼鏡を処方せず経過観察のみを行った ものである。

このうち10例に眼鏡を処方し、あとの16例は 経過観察をおこなった。眼鏡を処方していな い例の方が屈折異常は軽い傾向にはあるが、 眼鏡を装用するか否かは、屈折值の他、視力 の発達経過、障害のあるものはその状態など を考慮して決定した。

5 ) 外斜視

外斜視は49例で、恒常性外斜視 3 例、間歇 性外斜視46例であった。その偏位量を図 9 に 示す。輻輳不全型は 2 例のみで、その他は基 


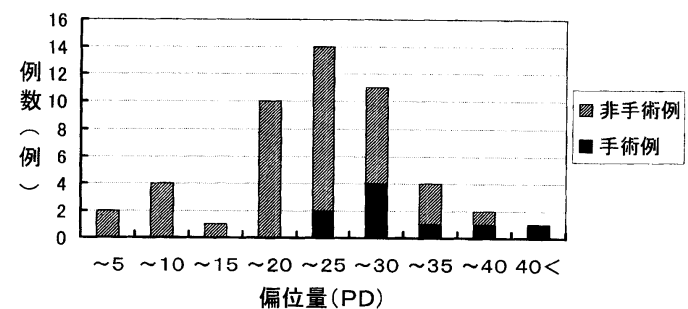

図 9 外斜視の偏位量 (遠見)

黒は手術を施行したもの、斜線は手術をして いないものである。

礎型であったため、遠見の偏位量で示してい る。15 $\triangle$ 以上がほとんどで、偏位量の少ない ものは輻輳不全型のものや他の異常で要精検 になったものであった。36例 $(73 \%)$ に手術 を考慮しながら経過観察を行ったが、2 例は 途中で転居、5 例は通院を中断してしまった ため、経過を追えたのは29例で、その中で実 際に手術を行ったものは 9 例 $(31 \%)$ であっ た。手術を行ったものの偏位量は $25 \triangle$ 以上で あった。手術を考慮しながら行っていない例 は、偏位量に変動のみられるもの、家族が希 望しないもの、就学までにまだ時間があるも のなどであった。残りの13例は手術は不要と 思われた。

6 ) 内斜視

内斜視は13例中で、12例に眼鏡を処方し、 そのうちの 4 例に弱視治療を行った。手術を した例はなかった。眼鏡装用により、6 例は 調節性内斜視で眼位が正位または斜位になり 両眼視も得られた。

\section{7 ）その他の斜視}

その他の斜視は 4 例で、上斜筋麻痺が 2 例、 下斜筋過動症が 2 例であった。全例に手術を 行った。

\section{8 ）その他の異常}

眼瞼下垂、朝顔症侯群、Duane症侯群、霞 粒腫、角膜混濁などがみられた。

\section{3 . 通院中断例}

治療中、または経過観察中に通院を中断した ものは31例 $(21 \%)$ あった。その中で 1 度だけ 来院したものは 8 例、 2 度来院したものは 4 例 あり、この12例の中には検査が十分できなかっ
た例や、不同視弱視や屈折異常弱視などで眼鏡 の装用を指示されたり、外斜視で偏位量が大き く手術を考慮する例が多かった。しばらく通院 した後（ 4 か月から 4 年 8 か月通院後）通院を 中断した例は19例で、この中には屈折異常はあ るが軽度なため眼鏡は作らず経過観察していた 例や、斜視があるものの偏位量が少なく経過観 察のみを行っていた例、弱視治療により視力が かなり向上し経過観察していた例など経過良好 例が多かった（表 2$) 。$

\section{表 2 通院を中断した例（31例）}

\begin{tabular}{l|c|c} 
1 2回で中断 & 例数 & 合計 \\
\hline 検査できず & 2 & \\
眼鏡装用指示(弱視) & 5 & 12 \\
畬視手術考盧 & 3 & \\
軽度屈折異常のみ & 2 & \\
& & \\
ある程度通院した後中断 & 例数 & 合計 \\
\hline 軽度屈折異常のみ & 5 & \\
軽度間歇性外斜視 & 5 & \\
内斜視(経過良好例) & 3 & 19 \\
弱視治療により経過良好 & 3 & \\
その他 & 3 &
\end{tabular}

\section{IV. 考按}

三歳児眼科検診の目的は、屈折異常や弱視、 斜視の早期発見、早期治療である。高柣市では、 二次検診に眼科医および視能訓練士が参加し、 フォトレフラクトメーターによる屈折検査を導 入して精度の高い検診を行ってきた ${ }^{1)}{ }^{2)}$ 。今回、 大阪医科大学病院眼科を受診した要精検児のう ち、要治療および要経過観察が96\%であり、異

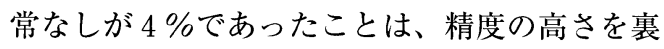
付けるものと考える。しかし、要精検児がその 後精密検查を受け、適切な治療、経過観察を受 けることが重要である。

弱視に関しては、治療を行えた屈折異常弱視、 不同視弱視のほとんどが就学前に矯正視力 (1.0) を獲得しており、検診の目的を十分果たしてい ると思われた。斜視弱視に関しては、治療によ り矯正視力（1.0）を獲得できた例もあるが、治 療を行っても視力がほとんど向上しない例が6例 中 2 例にみられた。斜視弱視の治療成績は三歳 
児での発見では十分とは言えず3)、さらに早期 に発見し治療を開始する必要があろう。

弱視のない屈折異常に関しては、屈折值、視 力の発達経過、障害のあるものはその状態など により、必要に応じて眼鏡処方することができ た。

斜視に関しては、外斜視の $73 \%$ 手術を考慮 しながら経過観察を行ったが、実際に手術を終

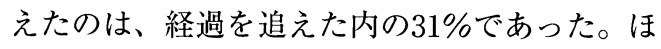
とんどが間歇性外斜視で、偏位量の他、斜視に なる頻度、両眼視機能、家族の希望などを考慮 して手術時期を決定している。手術を考慮しな がら行っていない例の中には就学までに時間の あるものも含まれているため、現状としては症 状における必要性や、希望に応じて就学までに 手術を行えていると考える。内斜視はほとんど に眼鏡装用を行い、その半数が眼位良好になっ たことから調節性内斜視を多く発見でき時期を 逃さず治療できたと考える。その他の斜視は上 斜筋麻盘や下斜筋過動症で、全例就学前に手術 を行った。

以上のように、治療、経過観察が継続できた ものについては、就学前に治療の大部分を終え ることができ、三歳児眼科検診の成果は十分み られたと思われる。

しかし、問題となるのは通院を中断した例で

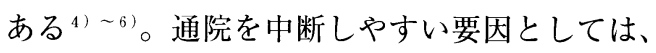
精検時に視力検査ができなかった例や、眼鏡矯 正にはいたらない軽度の屈折異常の例が多いと 言われている4)。また、眼鏡や手術を勧められ て不安になった場合、指示に従いたくないため 転々と主治医を変える場合、自分の子どもの病 状が理解できず “受診が面倒である”、“日常生 活を支障なく行っているのだから悪いはずはな い”などと考え放置している場合もあると言わ れている5)。今回、通院を中断した例は $21 \%$ あ り、1、2 回で通院を中断した例の中には、検 査が十分行えなかったもの、保護者が治療の必 要性を感じていなかったり、眼鏡や斜視手術を 受け入れられないためではないかと思われる例 が多かった。ある程度通院した後中断した例の
中には、弱視治療後の経過良好例や軽度屈折異 常または偏位量の少ない斜視で経過観察のみを 行っていた例が多く、受診を軽視したためでは ないかと思われた。これらの中断例をなくすに は、わかりやすく病状を説明し、この時期の治 療や経過観察の必要性を理解してもらう必要が ある。せっかく検診で異常が発見されても適切 な治療がなされないと検診の意味がなくなって しまう。また、弱視治療で視力が向上してもそ の後の適切な眼鏡の管理、弱視の再発を見逃さ ないこと、斜視に関しても眼位の変化を定期的 に観察していくことなど経過観察が必要な例は 多い。治療が必要であるにもかかわらず治療開 始前に中断してしまうことがないよう初診時の 対応を一層心がけるとともに、経過観察例にも その大切さを十分に伝える努力をしていきたい。

稿を終えるにあたり、ご校閲いただいた池田 恒彦教授に深謝いたします。

\section{参考文献}

1 ）中村桂子：これからの三歳児眼科検診. 日本 弱視斜視学会会報 $98: 14-25,1997$.

2 ）稲泉令巳子, 平尾真実, 中村桂子, 濱村美恵 子, 清水みはる, 筒井亜由美, 菅澤淳 : 高槻 市における三歳児眼科検診. 眼臨 $99: 223$ $226,2005$.

3 ）丸尾敏夫, 臼井千恵: 三歳児健康診査におけ る視力異常児の事後措置. 平成 6 年度厚生省 心身障害研究「少子化時代に対応した母子保 健事業に関する研究」366-375，1995.

4 ）伊藤説子，杉山真由美，橋本禎子，八子恵 子：三歳児視鸴検査における事後措置と問題 点. 眼臨 $89: 1378-1381,1995$.

5 ）黑田紀子：乳幼児健診と事後措置. 眼科診療 プラクティス $27: 60-63$, 文光堂, 東京, 1996.

6 ）八子恵子：小児眼疾患の早期発見早期治療 三歳児眼科健診を中心に一。本の眼科 $71: 533-536,2000$. 